\title{
Reticulon-4 Receptor-Like 1
}

National Cancer Institute

\section{Source}

National Cancer Institute. Reticulon-4 Receptor-Like 1. NCI Thesaurus. Code C158530.

Reticulon-4 receptor-like 1 (441 aa, $\sim 49 \mathrm{kDa}$ ) is encoded by the human RT N4RL1 gene.

This protein plays a role in axon migration and regeneration. 